\title{
Changes in selected biochemical blood parameters in dairy cows after administration of melatonin*
}

\author{
K. Darul and H. Kruczyńska ${ }^{1}$ \\ The August Cieszkowski Agricultural University of Poznań, \\ Department of Animal Nutrition and Feed Management \\ Wotyńska 33, 60-637 Poznań, Poland
}

\begin{abstract}
In order to investigate the effect of melatonin on indexes of blood carbohydrate-lipid processes, cows were given melatonin intravenously in the amount of $0.1 \mathrm{mg} / \mathrm{kg}$ body weight in the morning on the second day after calving. Blood samples were collected three times: before, $1 \mathrm{~h}$ and $4 \mathrm{~h}$ after injection. The administration of the pineal gland hormone resulted in a significant $(35 \%)$ increase in blood serum triglyceride (TG) concentrations and a nonsignificant (14\%) increase in cholesterol concentration. At the same time in the experimental group, a lower free fatty acid (FFAs) concentration (by 13\%) was observed along with lower values of FFA:TG and FFA: cholesterol ratios, while alanine aminotransferase (ALT) activity increased. The differences found in comparison with the control group were not significant. The glucose concentration and aspartate transferase (AST) activity did not change.
\end{abstract}

KEY WORDS: melatonin, dairy cows, blood indices

\section{INTRODUCTION}

Increased genetic capability for milk production coupled with changes in nutritional management have been associated with an increase in health and fertility problems (McNamara et al., 2003). Nutritional requirements change abruptly at parturition as milk production rapidly increases and cows develop a negative energy balance. This energy deficit makes the cow susceptible to metabolic diseases such as ketosis and fatty liver (McNamara, 2003; Darul and

\footnotetext{
* Supported by the State Committee for Scientific Research, Grant No. 3P06Z 01222

${ }^{1}$ Corresponding author: e-mail: hkruczyn@jay.au.poznan.pl
} 
Kruczyńska, 2004a). Studies conducted previously showed an advantageous effect of the pineal gland hormone on metabolism in laboratory animals (Maćkowiak et al., 1999; Mazepa et al., 2000; Nishida et al., 2002).

The aim of this study was to determine the effect of exogenous melatonin on indexes of carbohydrate-lipid processes in cows on the second day after calving.

\section{MATERIAL AND METHODS}

The experiment was conducted in the summer season on dairy cows aged $2-6$ years with mean yield of $7143 \mathrm{~kg} /$ year (6871- 8756). For the last 2 weeks before calving and immediately after calving the animals on grazing were fed additionally (kg DM): maize silage, 3.0; lucerne haylage, 2.0; grass haylage, 3.3, and mash, 3.4. Calving cows were included into the experiment successively with the division into two groups: I $(\mathrm{n}=10)$ and II $(\mathrm{n}=10)$. On the second day after calving at 7 a.m. the animals in group II received melatonin (SIGMA-ALDRICH, Poland) intravenously in the amount of $0.1 \mathrm{mg} / \mathrm{kg}$ body weight. Blood samples were collected before, 1 and $4 \mathrm{~h}$ after the administration of the hormone. Glucose, total cholesterol, triglycerides (TG), alanine transferase (ALT) and aspartate transferase (AST) activities were assayed in blood serum using DIALAB biochemical assays, while free fatty acids (FFAs) were determined using the Duncomb colorimetric method (1964). The FFA:TG and FFA: cholesterol ratios were calculated. The obtained data were analysed statistically using the SAS software package (1996) with the Duncan test.

\section{RESULTS AND DISCUSSION}

Table 1. Concentrations of selected blood serum parameters in cows after administration of melatonin

\begin{tabular}{|c|c|c|c|c|}
\hline \multirow{2}{*}{ Indices } & \multirow{2}{*}{ Group } & \multicolumn{3}{|c|}{ Time of sample collection, $\mathrm{h}$} \\
\hline & & 0 & 1 & 4 \\
\hline \multirow{2}{*}{$\mathrm{TG}, \mathrm{mmol} / \mathrm{L}$} & I & $0.21 \pm 0.03$ & $0.24 \pm 0.02$ & $0.20 \pm 0.02$ \\
\hline & II & $0.20 \pm 0.02$ & $0.26 \pm 0.01$ & $0.27 \pm 0.02^{\mathrm{A}}$ \\
\hline \multirow{2}{*}{ FFA, mmol/L } & I & $0.26 \pm 0.03$ & $0.30 \pm 0.05$ & $0.28 \pm 0.05$ \\
\hline & II & $0.30 \pm 0.06$ & $0.26 \pm 0.02$ & $0.28 \pm 0.06$ \\
\hline \multirow{2}{*}{ Cholesterol, $\mathrm{mmol} / \mathrm{L}$} & I & $2.18 \pm 0.13$ & $2.27 \pm 0.17$ & $2.09 \pm 0.09$ \\
\hline & II & $2.21 \pm 0.06$ & $2.59 \pm 0.17$ & $2.11 \pm 0.05$ \\
\hline \multirow{2}{*}{ FFA:TG } & I & $1.45 \pm 0.30$ & $1.35 \pm 0.28$ & $1.43 \pm 0.26$ \\
\hline & II & $1.54 \pm 0.33$ & $0.90 \pm 0.15$ & $1.16 \pm 0.29$ \\
\hline \multirow{2}{*}{ FFA:cholesterol } & I & $0.12 \pm 0.02$ & $0.14 \pm 0.03$ & $0.13 \pm 0.02$ \\
\hline & II & $0.13 \pm 0.03$ & $0.10 \pm 0.01$ & $0.13 \pm 0.03$ \\
\hline \multirow{2}{*}{ ALT, U/1 } & I & $14.52 \pm 1.97$ & $14.10 \pm 1.62$ & $13.24 \pm 1.92$ \\
\hline & II & $14.95 \pm 2.81$ & $15.55 \pm 4.23$ & $16.12 \pm 3.45$ \\
\hline \multirow{2}{*}{$\mathrm{AST}, \mathrm{U} / 1$} & I & $32.06 \pm 5.31$ & $35.46 \pm 5.75$ & $38.22 \pm 8.21$ \\
\hline & II & $34.47 \pm 4.25$ & $37.13 \pm 5.78$ & $38.96 \pm 5.22$ \\
\hline \multirow{2}{*}{ Glucose, $\mathrm{mmol} / \mathrm{l}$} & I & $2.92 \pm 0.18$ & $3.20 \pm 0.25$ & $3.13 \pm 0.26$ \\
\hline & II & $3.00 \pm 0.15$ & $3.20 \pm 0.52$ & $3.18 \pm 0.37$ \\
\hline
\end{tabular}

results are presented as means $\pm \mathrm{SEM},{ }^{\mathrm{A}}$ - statistically significant differences as $\mathrm{P} \leq 0.05$ 
The administration of melatonin resulted in a significantly advantageous increase in the concentration of triglycerides (35\%) alongside a concurrent nonsignificant decrease in the serum FFA (13\%) concentration. In a study by Darul and Kruczyńska (2004a) conducted on dairy cows on the second day after calving in the winter, injection of the pineal gland hormone also resulted in a significant increase in TG concentration, although with a nonsignificant decrease in FFA concentration. In contrast, changes in these indexes in goats after the hormone injection were statistically significant (Darul and Kruczyńska, 2004b). Also in the study by Maćkowiak et al. (1999) an increase in the serum triglyceride concentration in rats was accompanied by a decrease in the FFA concentration. It is suggested that the observed changes may be the effect of the action of melatonin on insulin concentration (Maćkowiak et al., 1999; Darul and Kruczyńska, 2004a,b).

In the conducted experiment, after melatonin administration an advantageous increase in cholesterol (14\%) concentration was observed, although these changes were not statistically significant. On the other hand, in another study by Darul and Kruczyńska (2004a,b), the hormone injection caused a significant increase in the concentration of cholesterol both in cows and goats.

One hour after the administration of melatonin the FFA:TG ratio was lower by $33 \%$ and the FFA:cholesterol ratio, lower by $20 \%$ in comparison with group I, with the differences being statistically nonsignificant.

In the study reported here, ALT activity $4 \mathrm{~h}$ after melatonin injection increased by $21 \%$. AST practically did not change. In previous investigations conducted by the authors of this study (Darul and Kruczyńska, 2004a,b) no effect of melatonin was observed on the activity of liver enzymes. In contrast, Calvo et al. (2001) and Montilla et al. (2001) reported a reduction in the enzyme activity in rats with hepatopathy after the injection of the hormone.

The glucose concentration did not change after the administration of the pineal gland hormone. In the experiment conducted by Darul and Kruczyńska (2004a) on dairy cows on the second day after calving, melatonin injections did not cause significant changes in the concentration of glucose. However, in milk goats it resulted in its significant increase (Darul and Kruczyńska, 2004b). As far as the participation of melatonin in carbohydrate metabolism is concerned, the data published so far (Maćkowiak et al., 1999; Mazepa et al., 2000), similarly to the results of these investigations, are not conclusive. 


\section{CONCLUSIONS}

The results obtained in this experiment showed that melatonin affects lipid metabolism, causing increased triglyceride and total cholesterol levels, decreased FFA levels, and FFA:TG and FFA:cholesterol ratios in cows.

\section{REFERENCES}

Calvo J.R., Reiter R.J., Garcia J.J., Ortiz G.G., Tan D.X., Karbownik M., 2001. Characterization of the protective effects of melatonin and related indoles against alpha-naphthylisothiocyanateinduced liver injury in rats. J. Cell Biochem. 80, 461-470

Darul K., Kruczyńska H., 2004a. Effect of melatonin on biochemical variables of the blood in dairy cows. Acta Vet. Hung. 52, 361-367

Darul K, Kruczyńska H., 2004b. Changes in selected blood metabolites associated with melatonin administration in dairy goats. Folia Biol. 52, 239-241

Duncombe P., 1964. The colorimetric micro-determination of nonesterifed fatty acids in plasma. Clin. Chim. Acta 9, 122-125

Maćkowiak P., Bejma E., Przybylska-Darul K., 1999. Acute melatonin action on insulin and thyroid hormones blood level and carbohydrate metabolism in rat. Rocz. Akad. Rol. Pozn. 51, 169-174

Maćkowiak P., Przybylska-Darul K., Bejma E., 1999. Changes in some lipid indices in rat blood, liver and muscles after injections of melatonin. Rocz. Akad. Rol. Pozn. 51, 175-180

McNamara S., Murphy J.J., Rath M., O’Mara F.P., 2003. Effects of different transition diets on energy balance, blood metabolites and reproductive performance in dairy cows. Livest. Prod. Sci. 84, 195-206

Mazepa R.C., Cuevas M.J., Collado P.S., Gonzáles-Galeo J., 2000. Melatonin increases muscle and liver glycogen content in nonexercised and exercised rats. Life Sci. 66, 153-160

Montilla P., Cruz A., Padillo F.J., Tunez I., Gascon F., Munoz M.C., Gomez M., Pera C., 2001. Melatonin versus vitamin $\mathrm{E}$ as protective treatment against oxidative stress after extra-hepatic bile duct ligation in rats. J. Pineal Res. 31, 138-144

\section{STRESZCZENIE}

\section{Zmiany w wybranych parametrach krwi krów mlecznych po podaniu melatoniny}

W celu sprawdzenia wpływu melatoniny na wskaźniki przemian węglowodanowo-lipidowych we krwi, krowom na drugi dzień po wycieleniu w godzinach porannych podano dożylnie melatoninę w ilości $0,1 \mathrm{mg} / \mathrm{kg}$ m.c. Próby krwi pobierano trzykrotnie: przed, w 1 i 4 godz. po iniekcji. Podanie hormonu szyszynki spowodowało istotny $35 \%$ wzrost koncentracji triglicerydów (TG) w surowicy krwi, równocześnie z 14\% nieistotnym wzrostem stężenia cholesterolu. W grupie doświadczalnej stwierdzono też niższą koncentrację wolnych kwasów tłuszczowych (WKT) (14\%) oraz niższe wartości ilorazów WKT:TAG i WKT:cholesterol w porównaniu z grupą kontrolną. Aktywność aminotransferazy alaninowej (ALT) wzrosła (różnica nieistotna), podczas gdy aktywność AST, podobnie jak koncentracja glukozy, nie uległy zmianie. 